\title{
Obtaining coke of improved quality by hydro- gentrification of coal tar
}

\author{
Nazym Smagulova ${ }^{1}$, Zhaxyntay Kairbekov ${ }^{1}$ and Gulsezim Yermekbayeva $^{1}$ \\ ${ }^{1}$ Al-Farabi Kazakh National University, 050040 Almaty, Kazakhstan
}

\begin{abstract}
The catalytic properties of non-applied nickel-sulfide catalysts in the reactions of hydrogenation and hydrodesulphurization of coal tar from the coal semi-coking of the Shubarkul field (Republic of Kazakhstan) were studied to obtain data necessary for the intensification of the resin processing technology, increasing the yield and improving the quality of the resulting needle coke. As a feedstock, the resin was used without preliminary dehydration (water content $3.4 \%$ ) and distillation in a mixture with the prepared catalyst and the residue of distillation with boiling point above $320^{\circ} \mathrm{C}$ of oil from the Kumkol field (Republic of Kazakhstan), taken in a mass ratio of 1:1.
\end{abstract}

\section{Introduction}

Coal tar is the most valuable chemical product of coking. A large place in the production is occupied by such products as pitch, coke and distillate light and heavy fractions, gasoline, phenol, naphthalene. Therefore, the role of coal tar as a raw material is important. The chemical composition of the coke-chemical resin and the resin fractions directly affects the properties of the resulting product. To date, an effective method for processing resin has not yet been fully studied. Therefore, the direction of obtaining coke by hydro-gentrification, to be more precise, hydrogenation of coal (coke-chemical) tar, was proposed.

The process of hydro-gentrification of heavy hydrocarbon raw materials takes place at high temperature, high pressure of hydrogen and in the presence of active catalysts. After many years of research, it becomes obvious that primary coal tar without preliminary dehydration and its fractions are the most valuable petrochemical raw materials with a huge chemical potential, from which a number of useful chemicals can be obtained.

Liquid products of hydrogenation of primary coal tar contain in their composition, in addition to heterocyclic compounds, a significant amount of aromatic hydrocarbons. If the removal of heterocyclic compounds, as well as the production of hydrocarbon fuels with improved environmental characteristics in the oil industry does not cause difficulties [1], then to reduce the content of aromatic hydrocarbons (from $45-50 \%$ to $20 \%$ or less) in the composition of coal tar, according to the standards [2], it is necessary to use new catalytic systems at the stage of hydro-gentrification. Hydro-gentrification of the mixture with coal tar allows to stabilize highly reactive compounds by saturating them with hydrogen.

For the processing of coal tar in accordance with the present invention, resin samples with a water content of 2.1-3.4 wt were used. \% and a density of $1.30-1.71 \mathrm{~g} / \mathrm{cm}^{3}$. 
Coal tar, despite the high temperature of its production $\left(900^{\circ} \mathrm{C}\right.$ and above), contains a significant amount of reactive compounds, which, when heated to a temperature of $350^{\circ} \mathrm{C}$ $400^{\circ} \mathrm{C}$ at which it is usually distilled at existing production facilities, are subjected to condensation with the formation of high-molecular compounds that prevent the production of needle coke at the stage of coking pitch fractions.

Also, the coal tar samples contained $12-14 \%$ fractions insoluble in toluene ( $\alpha$-fraction) and $2-3 \%$ insoluble in quinolone ( $\alpha_{1}$ - fraction).

To reduce the fraction of fractions insoluble in quinoline, the initial coal tar containing up to $5 \%$ water was mixed with a catalyst $(0.03-0.1 \% \mathrm{Mo}, \mathrm{Ni}, \mathrm{Fe}$, and other elements in the form of water-soluble salts) and with additional components.

\section{Experimental}

An important factor in the active stabilization of reactive compounds of coal tar before its preparation (heating during distillation, coking pitch, etc.) is the use of fine-crystalline compounds $\mathrm{Mo}, \mathrm{Ni}, \mathrm{Fe}$, etc. metals that have a crystallite size commensurate with the size of the raw material molecules and formed in a reaction medium from an aqueous emulsion during the heating of the raw material by micro-explosions of the emulsion bubbles and a uniform distribution of the catalyst in the raw material. To achieve this goal, the coal tar containing up to $5 \%$ water, mainly $3 \%$ water, was added to the salts of the elements listed earlier, the mixture with the coal tar was dispersed to a certain size of water droplets in a special device. The amount of catalyst added to the raw material was $0.02-1 \%$ per metal.

The preparation of the catalyst was carried out by adding an aqueous solution of $3.0 \%$ nickel nitrate (wt.) from the raw material, as well as the sulfidation additive of elemental sulfur (in powder form) in the amount of $0.03 \%$ by weight of the catalyst. The Ni concentration was $0.025 \%$ (wt.) per raw material. The resulting mixture was dispersed in a homogenizer at a temperature of $130^{\circ} \mathrm{C}$ and a plate rotation speed of $1500 \mathrm{rpm}$. The resulting mixture was hydrogenated. During the hydrogenation of the mixture, these metal salts under the action of hydrogen sulfide released in the process are subjected to transformations into the corresponding metal sulfides, which are directly catalysts of the process.

The experiments were carried out in a high-pressure laboratory installation with reactor with a volume of $0.25 \mathrm{dm}^{3}$ and a mixing device. The working pressure of hydrogen was 5.0 $\mathrm{MPa}$, the temperature was $350-450^{\circ} \mathrm{C}$, the reaction time was $15 \mathrm{~min}$. These technological parameters were selected on the basis of the results of our previous studies on the hydrorefining of coal tar of the ShubarKul coal semi-coking field in the presence of a nano heterogenic molybdenum sulfide catalyst synthesized in situ from an aqueous solution of ammonium paramolybdate [3], as a result of which it was found that $5 \mathrm{MPa}$ and $400^{\circ} \mathrm{C}$ are the optimal technological parameters for deep processing of the resin.

To obtain raw materials for the production of coke, the resin hydrogenates were filtered at a temperature of $180^{\circ} \mathrm{C}$, at a pressure of $1.0 \mathrm{MPa}$ through a belting cloth with two layers of filter paper at a filtration rate of $14-15 \mathrm{~kg}$ per $\mathrm{min} / \mathrm{m} 2$.

The filtrates were dispersed by distillation into fractions with a boiling point of up to $280^{\circ} \mathrm{C}$ and the remainder with a boiling point above $280^{\circ} \mathrm{C}$ (raw materials for the production of electrode coke), which was coked in a laboratory reactor at a final temperature of $620^{\circ} \mathrm{C}$. 


\section{Results and Discussion}

According to the data presented in Tables 1-2, it can be seen that the total yield of distillate fractions of motor fuels in the presence of a molybdenum catalyst was a maximum of $76.8 \%$ at a temperature of $400^{\circ} \mathrm{C}$. When hydro-gentrification the resin in the presence of a nickel catalyst under similar conditions, the yield of liquid products was slightly higher $78.3 \%$.

Table 1. Results of tar hydrogenation (5.0 MPa, $\tau=15 \mathrm{~min}$, tar: oil paste-forming agent $=1: 1$, highpressure laboratory unit).

\begin{tabular}{|c|c|c|c|c|c|c|c|c|}
\hline \multicolumn{9}{|c|}{ Without catalyst and sulfur additives } \\
\hline \multirow{5}{*}{$\begin{array}{l}\text { Process } \\
\text { perform } \\
\text { ance } \\
\text { indicato } \\
\text { rs }\end{array}$} & \multirow[t]{2}{*}{$\begin{array}{l}\text { Tempe } \\
\text { rature, } \\
{ }^{\circ} \mathrm{C}\end{array}$} & \multicolumn{3}{|c|}{$\begin{array}{c}\text { Yield of liquid } \\
\text { products with poiling } \\
\text { point }{ }^{\circ} \mathrm{C}, \% \text { (mass.) }\end{array}$} & \multirow{2}{*}{$\begin{array}{c}\text { Total } \\
\text { yield of } \\
\text { distillate } \\
\text { fraction } \\
\text { s, } \%\end{array}$} & \multirow[t]{2}{*}{$\begin{array}{c}\text { Gas }+\mathrm{H}_{2} \mathrm{O}, \\
\% \text { (mass.) }\end{array}$} & \multirow[t]{2}{*}{$\begin{array}{c}\text { Sludge, \% } \\
\text { (mass.) }\end{array}$} & \multirow[t]{2}{*}{$\begin{array}{c}\text { Loss, } \\
\% \text { (mass.) }\end{array}$} \\
\hline & & $>180$ & $\begin{array}{l}180- \\
250\end{array}$ & $\begin{array}{l}250- \\
320\end{array}$ & & & & \\
\hline & 350 & 5.3 & 11.4 & 13.2 & 29.9 & 36.0 & 16.2 & 17.9 \\
\hline & 400 & 7.8 & 15.3 & 24.0 & 47.1 & 36.3 & 9.1 & 7.5 \\
\hline & 450 & 10.3 & 7.6 & 12.9 & 30.8 & 36.0 & 19.3 & 13.9 \\
\hline
\end{tabular}

The filtrate yields were $90 \%$ for the hydrogenate obtained in the presence of a molybdenum catalyst, and $94.5 \%$ in the presence of a nickel catalyst. The solid content in them was 1.7 and $1.3 \%$, respectively, and the solid content in the sediment was 34.7 and $50.9 \%$, i.e., when using a nickel catalyst, a hydrogenate is obtained that is more suitable for filtration. The Mo content in the filtrate was $0.0003 \%$, in the filtration residue $-1.3 \%$, Ni$0.0013 \%$ and $0.8 \%$, respectively, which indicates that the main amount of the catalyst used is concentrated in the solid residue and can be returned to the process by adding to a new portion of the resin. Distillate fractions with a boiling point of up to $280^{\circ} \mathrm{C}$ consisted mainly of mono - and bicyclic aromatic hydrocarbons, including naphthalene up to $15 \%$, monomethyl naphthalene-up to $7 \%$, and should be sent for processing together with the products of hydro-gentrification of the tar.

After distilling the resin to obtain a fraction with a boiling point of up to $330^{\circ} \mathrm{C}$ and a residue (heating to $360^{\circ} \mathrm{C}$ ), the content ( $\alpha$ - fraction) in the residue was $29.6 \%$, which was $19.6 \%$ in terms of coal tar and the $\alpha_{1}$ - fractions was $5-7 \%$, respectively.

The duration of coking was 7 hours, the final temperature was $620^{\circ} \mathrm{C}$, the temperature rise rate was 1.25 degree $/ \mathrm{min}$. Gas was taken at $465^{\circ} \mathrm{C}$ and $540^{\circ} \mathrm{C}$. The output of coke was $46.1 \%$, distillate $41.3 \%$, gas + losses $12.7 \%$.

To determine the quality indicators, the coke sample was calcined at $1300^{\circ} \mathrm{C}$ with an exposure of 5 hours in accordance with GOST 22898-78. The coke has a true density index, which is usually characteristic of ordinary non-isotropic coke, which is characteristic of cokes with a high degree of texturization. 
Table 2. Results of tar hydrogenation ( $5.0 \mathrm{MPa}, \tau=15 \mathrm{~min}$, tar: oil paste-forming agent $=1: 1$, highpressure laboratory unit)

\begin{tabular}{|c|c|c|c|c|c|c|c|c|}
\hline \multicolumn{9}{|c|}{ Using nanoheterogenic $\mathrm{Ni}$ and Mo-containing catalysts } \\
\hline \multirow{2}{*}{$\begin{array}{c}\text { Proce } \\
\text { ss } \\
\text { perfo } \\
\text { rman } \\
\text { ce } \\
\text { indica } \\
\text { tors }\end{array}$} & \multirow[t]{2}{*}{$\begin{array}{l}\text { Temper } \\
\text { ature, } \\
\quad \text { C }\end{array}$} & \multicolumn{3}{|c|}{$\begin{array}{c}\text { Yield of liquid } \\
\text { products with poiling } \\
\text { point }{ }^{\circ} \mathrm{C}, \% \text { (mass.) }\end{array}$} & \multirow{2}{*}{$\begin{array}{c}\text { Total yield } \\
\text { of distillate } \\
\text { fractions, } \\
\%\end{array}$} & \multirow[t]{2}{*}{$\begin{array}{l}\text { Gas+ H2O, } \\
\% \text {, (mass.) }\end{array}$} & \multirow[t]{2}{*}{$\begin{array}{c}\text { Sludge,\%, } \\
\text { (mass.) }\end{array}$} & \multirow[t]{2}{*}{$\begin{array}{c}\text { Loss, } \\
\% \text {,(ma } \\
\text { ss.) }\end{array}$} \\
\hline & & $\begin{array}{c}> \\
180\end{array}$ & $\begin{array}{l}180- \\
250\end{array}$ & $250-320$ & & & & \\
\hline \multirow{3}{*}{$\begin{array}{l}0.025 \\
\% \mathrm{Ni} \\
+0.0 \\
3 \% \mathrm{~S}\end{array}$} & 350 & 2.3 & 15.8 & 43.4 & 61.5 & 15.5 & 14.1 & 8.9 \\
\hline & 400 & 2.7 & 23.2 & 52.4 & 78.3 & 8.7 & 9.0 & 4.0 \\
\hline & 450 & 2.8 & 17.0 & 48.4 & 68.2 & 15.5 & 13.3 & 3.0 \\
\hline \multirow{3}{*}{$\begin{array}{l}0.025 \\
\% \mathrm{Mo} \\
+0.0 \\
3 \% \mathrm{~S}\end{array}$} & 350 & 2.3 & 15.2 & 42.0 & 58.5 & 22.8 & 14.5 & 4.2 \\
\hline & 400 & 2.7 & 22.8 & 52.3 & 76.8 & 8.2 & 9.2 & 5.8 \\
\hline & 450 & 2.8 & 11.5 & 38.8 & 51.5 & 26.4 & 14.2 & 7.9 \\
\hline
\end{tabular}

Thus, as in the case of using a Mo - catalyst, hydrogenation of a mixture with coal tar with a Ni-catalyst allows you to obtain raw materials for the production of coke with an improved structure (needle).

\section{Conclusion}

The direction of production of Coke with improved quality by hydrogenating enrichment of the boiling fraction at a temperature above $230^{\circ} \mathrm{C}$, obtained by distillation of coal resin at low hydrogen pressure (4.0-5.0 MPA) in MO and Ni catalysts, was proposed. According to GOST 22898-78, Coke samples were burned at $1300^{\circ} \mathrm{C}$ and Coke was obtained, which had a true density of $2.14 \mathrm{~g} / \mathrm{cm}^{3}$ and a microstructure of 4.9 points.

\section{References}

1. A.A Krichko, Hydrogenation of coal in the USSR, Engineer's Library, 47 (1984)

2. A.A. Krichko, N.Yu. Beylina, V.V. Zamanov, A.A. Ozarenko, Ye.A. Ozarenko, S.B. Frosin, Solid Fuel Chem. 5, 22 (2006)

3. N.T. Smagulova, Zh.K. Kairbekov, A.S. Maloletnev, L.K. Kudreeva, A.N. Sabitova, Solid Fuel Chem., 4, 32 (2020) 